\title{
Minimal hodeskade som ble akutt verre
}
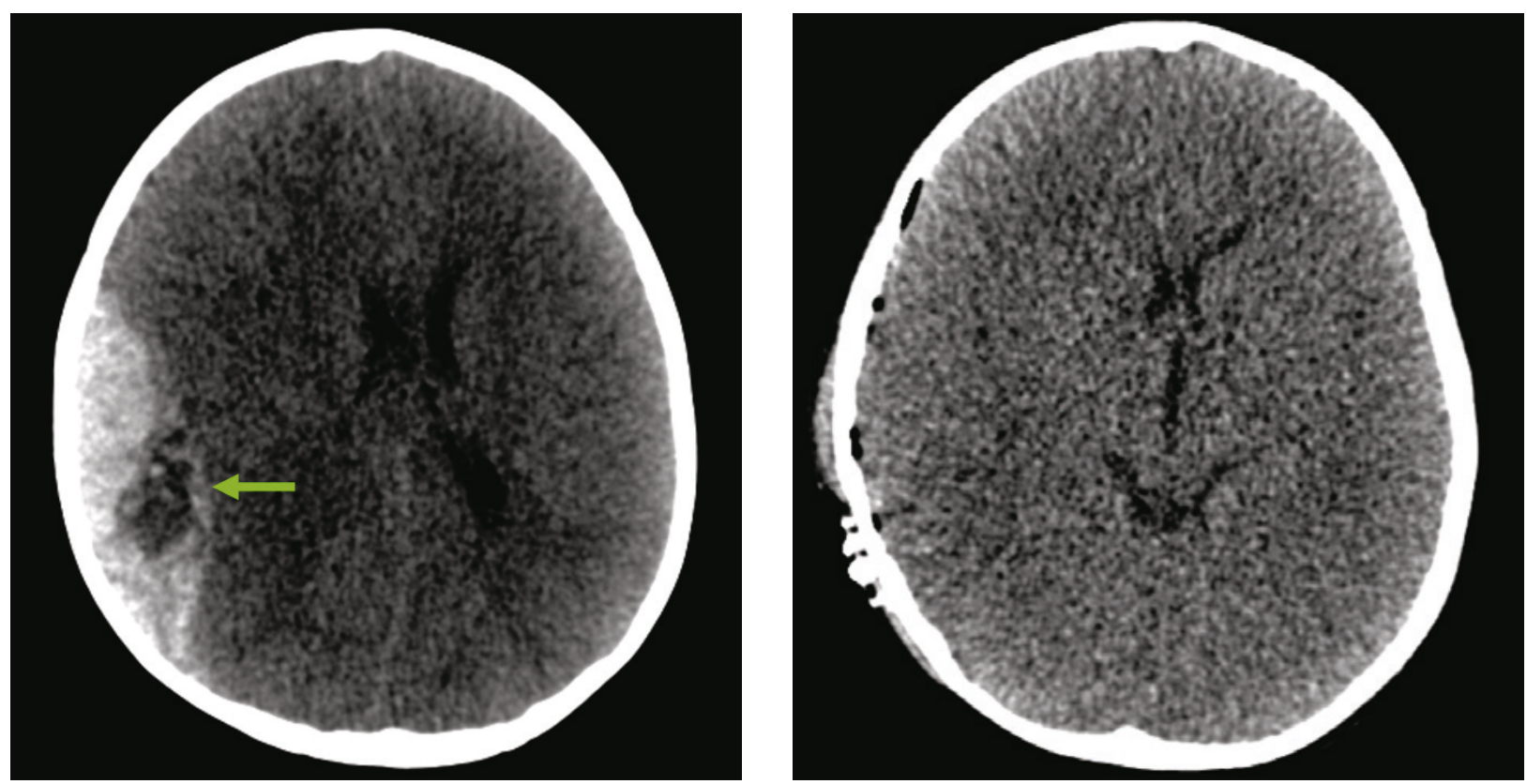

En ettermiddag landet helikopteret på taket av sykehuset. I akuttmottaket sto traumeteamet klart til å ta imot en 18 måneder gammel gutt. Fem timer tidligere hadde han falt fra sin egen høyde i en utendørs steintrapp og slått hodet mot en murkant. Han var kjekk umiddelbart etter fallet, og det ble ikke observert bevissthetstap.

Gutten ble undersøkt på den lokale legevakten og hadde da normal Glasgow Coma Score på 15 (vurdert med pediatrisk GCS-versjon). Det var ingen ytre tegn til hodeskade. I samsvar med skandinaviske retningslinjer for mindre alvorlige hodeskader ble han og foreldrene sendt hjem med et informasjonsskriv samt beskjed om å ta kontakt ved tegn til forverring (1). Utover ettermiddagen ble han vanskelig å få kontakt med, og foreldrene ringte nødtelefonen 113. Situasjonen ble oppfattet som alvorlig, og luftambulanse rykket ut.

I akuttmottaket åpnet han så vidt øynene på sterke smertestimuli, laget kun enkelte lyder og hadde målrettede avvergebevegelser, dvs. Glasgow Coma Score 9 (pediatrisk GCS-versjon). Etter en rask klinisk undersøkelse ble det utført CT-undersøkelse av hodet. Den viste et stort epiduralt hematom på høyre side, med masseeffekt og midtlinjeoverskyting (bildet til venstre). Man så også det som blir kalt «swirl sign», som indikerer en pågående og kraftig blødning (grønn pil) (2). På vital indikasjon ble han tatt direkte til Nevrokirurgisk operasjonsstue, der det ble gjort en kraniotomi med evakuering av hematomet. Ny CT-undersøkelse av hodet dagen etter viste pene postoperative forhold (bildet til høyre).

Noen måneder senere kom gutten til kontroll på Nevrokirurgisk poliklinikk. Etter grundig undersøkelse fant man ingen sekveler - det var normal motorikk og normal språkutvikling.

God informasjon til foreldrene på legevakten, riktige prehospitale vurderinger og rask diagnostikk og behandling er trolig årsaken til at det gikk så bra.

Barnets foreldre har gitt samtykke til at artikkelen blir publisert.

\section{Vidar Rao}

vidarrao@gmail.com

Nevrokirurgisk avdeling

St. Olavs hospital

Institutt for nevromedisin

Norges teknisk-naturvitenskapelige universitet

\section{Kjell Arne Kvistad}

Klinikk for billeddiagnostikk

St. Olavs hospital

og

Institutt for sirkulasjon og billeddiagnostikk

Norges teknisk-naturvitenskapelige universitet

\section{Sasha Gulati}

Nevrokirurgisk avdeling

St. Olavs hospital

og

Institutt for nevromedisin

Norges teknisk-naturvitenskapelige universitet
Vidar Rao (f. 1982) er ph.d., førsteamanuensis og lege i spesialisering i nevrokirurgi.

Forfatter har fylt ut ICMJE-skjemaet og oppgir ingen interessekonflikter.

Kjell Arne Kvistad (f. 1960) er dr.med., førsteamanuensis, overlege og spesialist i radiologi. Forfatter har fylt ut ICMJE-skjemaet og oppgir ingen interessekonflikter.

Sasha Gulati (f. 1981) er ph.d., forsker, overlege og spesialist i nevrokirurgi.

Forfatter har fylt ut ICMJE-skjemaet og oppgir ingen interessekonflikter.

\section{Litteratur}

1. Ingebrigtsen T, Romner B, Kock-Jensen C Scandinavian guidelines for initial management of minimal, mild, and moderate head injuries. J Trauma 2000; 48: 760-6.

2. Al-Nakshabandi NA. The swirl sign. Radiology 2001; $218: 433$

Mottatt 20.2. 2013, første revisjon innsendt 22.4 2013, godkjent 7.5. 2013. Medisinsk redaktør Merete K. Holtermann. 